\title{
Current Research in the Sabine Mine's Rusk Permit, Rusk County, Texas
}

Ross C. Fields

Prewitt and Associates, Inc.

John E. Dockall

Follow this and additional works at: https://scholarworks.sfasu.edu/ita

Part of the American Material Culture Commons, Archaeological Anthropology Commons, Environmental Studies Commons, Other American Studies Commons, Other Arts and Humanities Commons, Other History of Art, Architecture, and Archaeology Commons, and the United States History Commons

Tell us how this article helped you.

This Article is brought to you for free and open access by the Center for Regional Heritage Research at SFA ScholarWorks. It has been accepted for inclusion in Index of Texas Archaeology: Open Access Gray Literature from the Lone Star State by an authorized editor of SFA ScholarWorks. For more information, please contact cdsscholarworks@sfasu.edu. 


\section{Current Research in the Sabine Mine's Rusk Permit, Rusk County, Texas \\ Creative Commons License \\ (c) (1) (9)}

This work is licensed under a Creative Commons Attribution-NonCommercial 4.0 International License 


\title{
Current Research:
}

\section{Current Research in the Sabine Mine's Rusk Permit, Rusk County,} Texas

\author{
Ross C. Fields and John E. Dockall \\ Prewitt and Associates, Inc.
}

\begin{abstract}
In 2014-2015, Prewitt and Associates, Inc., conducted test excavations at seven Native American sites-41RK674, 41RK680, 41RK693, 41RK695, 41RK703, 41RK704, and 41RK729-in northeast Rusk County, Texas (Fischbeck et al. 2015). These sites are in Area W of the South Hallsville No. 1 Mine's Rusk Permit, which is operated by North American Coal Corporation-Sabine Mine (Figure 1). The excavations consisted of $92 \mathrm{~m}^{2}\left(80.7 \mathrm{~m}^{3}\right)$ of hand-dug test units and 63 backhoe trenches $\left(702 \mathrm{~m}^{2}\right)$.
\end{abstract}

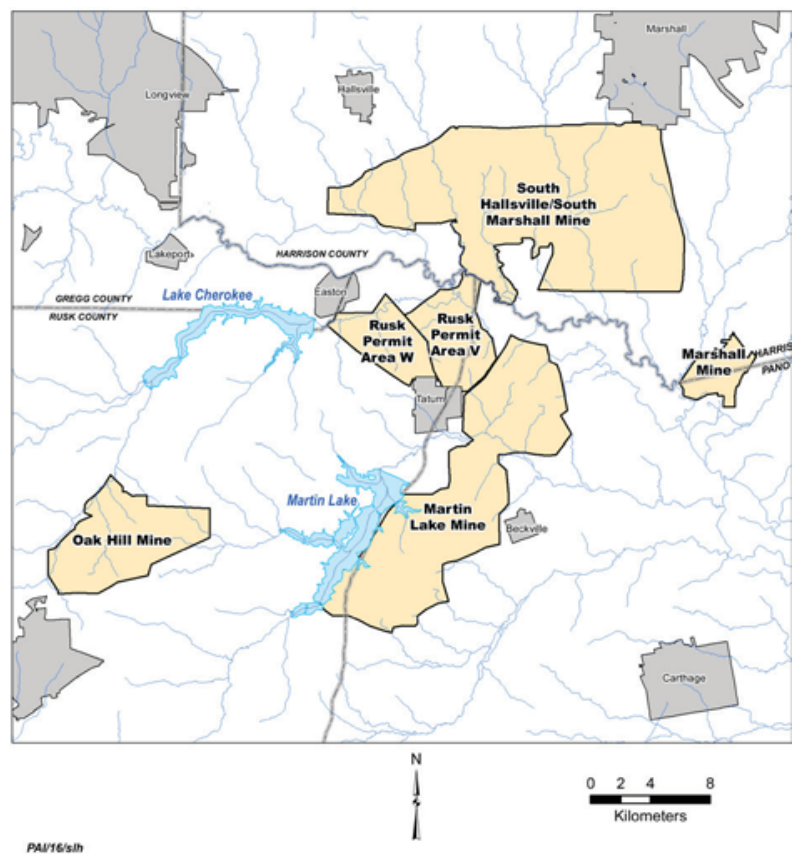

Figure 1. Map showing the location of Rusk Permit Area $\mathrm{W}$ relative to other nearby areas investigated archeologically.

Testing determined that the sites have components dating as early as the Middle Archaic period (ca. 3500 B.C.) and as late as the Late Caddo period (late A.D. 1400s), with Late Archaic, Woodland, Early Caddo, and Middle Caddo components represented as well. Four sites have moderate to high densities of cultural materials representing substantial Native American occupations, although none have middens indicating especially prolonged use. Sites 41RK674 and
41RK693 are interpreted as Late Caddo and Middle Caddo farmsteads, respectively, albeit briefly occupied ones. Site 41RK703 has prominent Middle Archaic and probably Late Archaic components representing repeated use as a campsite, with lesser Woodland and Early Caddo components indicating non-residential use. The primary component at 41RK704 represents repeated use during the Woodland period as a special-purpose campsite, and a secondary Early Caddo component reflects less-intensive use as a procurement/processing location or short-term campsite. The other three sites were used less intensively, with 41RK680 having a Woodland component, 41RK695 having a Late Caddo component, and 41RK729 having an unidentified Caddo component; these sites likely were used as procurement or processing locations or short-term campsites.

Although all seven sites suffer from the lack of preserved feature assemblages, the data from them are useful for gaining a better understanding of how Native Americans used this part of the Sabine River valley. This can be achieved through comparisons with survey and excavation data from Rusk Permit Area V to the east and Sabine Mine's South Hallsville/Marshall Mine on the north side of the Sabine River, as well as Martin Lake Mine just to the east and Oak Hill Mine not far to the southwest. Survey data indicate that the density of prehistoric sites is not even across the Rusk Permit, with prehistoric sites most common in Pleistocene terrace and valley wall settings at the south edge of the Sabine River floodplain in the eastern part (Area V) and on the Cherokee Bayou floodplain in the western part (Area W). These settings provided access to water resources such as Hendricks Lake, Black Slough, and Cherokee Bayou. In addition, parts of these landforms provided arable farmland where Caddo Indians could have grown crops. Sites are much less common in upland areas back from the valley wall. One reason for the low density of upland sites appears to be the scarcity of sufficient and stable water sources. Although springs are present in upland settings, particularly along the interface between the uplands and Pleistocene terrace segments, they are mostly at runoff-fed drainages and lack continual flow. The few prehistoric sites found along these drainages are mostly lithic scatters. 
The site density for the almost 9,500 acres of surveyed land in the Rusk Permit overall (one site per 143 acres) is much lower than that for the surveyed parts of the Sabine Mine north of the river (one site per 80 acres). This probably relates at least partly to the fact that the north side of the river is drained by a number of perennial south-flowing tributaries that create a multitude of ideal settings for Native American occupation sites, while the uplands south of the river are drained by intermittent streams. Hence, Native American settlement strategies in this region, during some time periods anyway, may have been oriented more toward tributaries than the Sabine River.

The site density data from Martin Lake Mine and Oak Hill Mine suggest that something more may have been going on, though, with prehistoric sites being even scarcer in both of these (one site per 432 and 507 acres, respectively) than in the Rusk Permit area. Although both Martin Lake and Oak Hill consist of large expanses of uplands where sites should be infrequent, both also contain perennial tributary stream valleys where one would expect high site densities. Indeed, sites are present along these streams, and some of these sites, such as Oak Hill Village (41RK214, Rogers and Perttula 2004), reflect intensive and long-term use. But the low densities of prehistoric sites suggest that, overall, the uplands south of the Sabine River were sparsely settled compared to the area north of the river. For at least parts of the late prehistoric Caddo period, this could indicate that the area south of the river was a buffer zone between intensively used parts of the Sabine River valley to the north and the Neches River valley to the south.

Regardless of the merit of the buffer zone hypothesis, it is certain that the Native Americans who occupied the south edge of the Sabine River valley were parts of larger communities. Sites 41RK703 and 41RK704 in Area W probably were used as procurement or processing locations and campsites by people who lived at the Early Caddo Hudnall-Pirtle ceremonialcivic center (41RK4) not far away (Figure 2), and this may be true for one of the tested sites in Area $\mathrm{V}$ to the east as well (41RK562). Site 41RK674 in Area W and probably 41RK557 in Area V were briefly occupied farmsteads associated with the Late Caddo Pine Tree Mound community centered on Potters Creek north of the Sabine River, with a secondary ceremonial center at the Lane Mitchell site closer to the river. Site 41RK693 in Area $\mathrm{W}$ was contemporaneous with the early part of that same community and could have been associated with it as well, or it may have been more connected to the Middle Caddo community anchored by the Oak Hill Village site farther away to the southwest. Based on the survey evidence, there are few other sites like these in the 12-km-long stretch of Sabine River valley wall within the Rusk Permit, though, and thus use of this area for outlying farmsteads during the Middle and Late Caddo periods was not common. Even when the Caddo did establish farmsteads in this area, it appears, based on the absence of middens at the tested sites, that they used them only briefly.

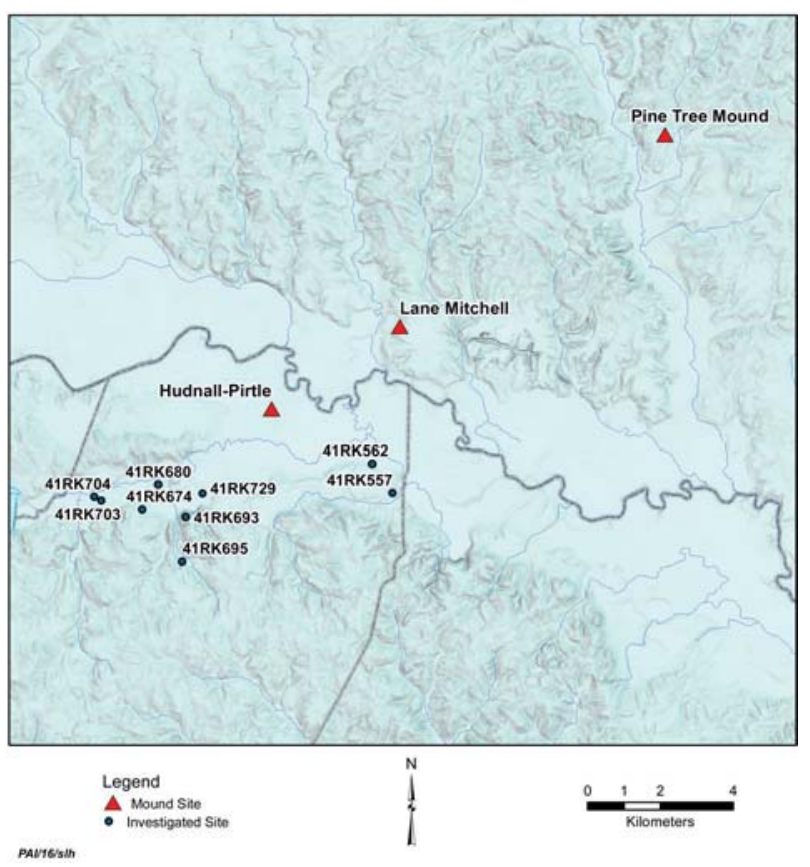

Figure 2. Map showing the locations of tested sites in the Sabine Mine's Rusk Permit and nearby Caddo mound sites.

\section{References Cited}

Fischbeck, Shelly L., John E. Dockall, E. Frances Gadus, and Ross C. Fields

2015 National Register Testing of Seven Native American Sites in the South Hallsville No. 1 MineRusk Permit, Area W, Rusk County, Texas. Report of Investigations No. 178. Prewitt and Associates, Inc., Austin, Texas.

Rogers, Robert, and Timothy K. Perttula

2004 The Oak Hill Village Site (41RK214), Rusk County, Texas. Document No. 030083. PBS\&J, Austin, Texas. 